J-ABDIPAMAS (Jurnal Pengabdian Kepada Masyarakat)

Vol. $2 \bullet$ No. $2 \bullet 2018$

ISSN : 2581-1320 (Print) ISSN : 2581-2572 (Online)

Homepage: http://ejurnal.ikippgribojonegoro.ac.id/index.php/J-ABDIPAMAS

\title{
SOSIALISASI BAHASA INGGRIS BEREKUIVALEN TOEFL (TEST OF ENGLISH AS A FOREIGN LANGUAGE) BAGI GURU YAYASAN NARA KREATIF JAKARTA TIMUR
}

\author{
Rr.Astri Indriana Octavita1 ${ }^{1}$, Ria Saraswati², Andi Santoso ${ }^{3}$ \\ 1Universitas Indraprasta PGRI, Email: mrs.astriindriana@gmail.com \\ 2Universitas Indraprasta PGRI, Email: riri.saraswati@gmail.com \\ 3Universitas Indraprasta PGRI, Email: andynabil@gmail.com
}

\begin{abstract}
The purpose achieved in this community service is to provide English language socialization to TOEFL as it can be one of the efforts to improve English mastery skills for teachers. The material in the socialization provided includes basic competence that are very useful to support the ability to communicate both oral and written. The materials are structure of English, reading, and listening. The structure of English language is the basis competence for mastering other basic skills because a good mastery on language structure can significantly improve the ability in other languages. These three basic competence are the basic elements of learning English for both academic and practical purposes. This socialization is expected to help teachers both English and non-English teachers to motivate themselves and to optimize their potential in English so that they can make a significant contribution to the school, and even for the development of their own careers.
\end{abstract}

Keywords: TOEFL, English Language, socialization, equivalent

\begin{abstract}
ABSTRAK
Tujuan diadakannya kegiatan pengabdian masyarakat ini adalah untuk memberikan sosialisasi Bahasa Inggris berekualensi TOEFL salah satu upaya yang dapat dilakukan untuk meningkatkan kemampuan penguasaan bahasa Inggris bagi guru. Materi dalam sosialisasi yang diberikan mencakup kemampuan dasar yang sangat berguna untuk menunjang kemampuan berkomunikasi baik lisan maupun tertulis. Materi tersebut adalah struktur bahasa Inggris, membaca, dan menyimak. Struktur bahasa Inggris merupakan dasar bagi penguasaan kemampuan dasar yang lain karena dengan penguasaan struktur bahasa yang baik, kemampuan dalam bidang bahasa yang lain secara signifikan dapat ditingkatkan. Ketiga kemampuan dasar tersebut merupakan elemen dasar dalam pembelajaran bahasa Inggris, baik untuk tujuan akademik maupun untuk tujuan praktis. Dengan adanya sosialisasi ini diharapkan dapat membantu para guru baik guru bahasa Inggris maupun guru non bahasa Inggris untuk memotivasi diri dan mengoptimalkan potensi yang mereka miliki dalam bahasa Inggris sehingga mereka dapat memberikan sumbangan yang berarti bagi sekolah, dan terlebih lagi bagi pengembangan karier mereka sendiri.
\end{abstract}

Kata Kunc : TOEFL, Bahasa Inggris, Sosialisasi, Berekuivalen 


\section{PENDAHULUAN}

Persaingan global dalam berbagai bidang menuntut penguasaan kompetensi dan akademik yang memadai dan dapat dipertanggungjawabkan. Dalam dunia pendidikan nasional Indonesia berbagai bentuk upaya telah dilakukan sebagai persiapan untuk menghadapi persaingan global ini, terutama untuk menghasilkan lulusan yang mampu bersaing, baik untuk melanjutkan ke jenjang pendidikan yang lebih tinggi maupun dalam dunia kerja. Selain upaya-upaya yang dilakukan pemerintah melalui Departemen Pendidikan Nasional, berbagai upaya juga dilakukan secara mandiri oleh berbagai sekolah, baik dasar, menengah maupun pendidikan tinggi, antara lain dengan mencanangkan mutu pendidikan dan membentuk generasi yang memiliki wawasan luas yang mampu bersaing di era globalisasi. Komitmen ini sebenarnya memiliki implikasi dan konsekuensi yang tidak kecil bagi sekolah/lembaga pendidikan yang bersangkutan. Banyak hal yang harus dilakukan, mulai dari pembenahan fasilitas, perbaikan kurikulum, pengembangan materi ajar, perbaikan sistem pengelolaan administrasi maupun akademik, dan yang paling mendasar, peningkatan kemampuan sumber daya manusia yang akan menjalankan dan mendukung komitmen tersebut.

Dalam upaya peningkatan kualitas sumber daya manusia di dunia pendidikan, penguasaan bahasa asing, terutama bahasa Inggris, merupakan suatu hal yang sangat penting. Hal ini didasari atas berbagai pertimbangan. Ketika pihak sekolah ingin mengembangkan mutu sekolah dengan menghasilkan lulusan yang mampu bersaing dalam era globalisasi, maka kemampuan bahasa Inggris merupakan suatu keharusan yang pada era global dan komunikasi saat ini. Yayasan Nara Kreatif merupakan lembaga kewirausahaan sosial yang menerapkan Green Living dalam bisnis, berfokus pada; permasalahan limbah kertas dan organik, membina serta memberdayakan anak jalanan, anak putus sekolah, dan anak pra-sejahtera. Yayasan Nara Kreatif menyediakan sarana dan prasarana pendidikan bebas biaya (Sekolah Kejar Paket) dari hasil penjualan pengolahan limbah kertas/organik secara berkesinambungan. Selain itu juga mengembangkan potensi diri dan pola pikir anak asuh melalui program asrama.

Sejak tahun 2013 Sekolah Kejar Paket Gratis Nara telah memberikan pendidikan gratis kepada 253 siswa di Kampung Dukuh dan sekitarnya. Latar belakang mereka adalah masyarakat dengan ekonomi kurang, namun memiliki keinginan kuat untuk mendapatkan kehidupan yang lebih baik. Sekolah Kejar Paket Yayasan Nara Kreatif berupaya untuk juga meningkatkan kemampuan penguasaan bahasa Inggris, terutama bagi guru-guru bahasa Inggris dan non bahasa Inggris.

Sosialisasi Bahasa Inggris berekualensi TOEFL merupakan salah satu upaya yang dapat dilakukan untuk meningkatkan kemampuan penguasaan bahasa Inggris bagi guru dan karyawan. Materi dalam sosialisasi yang diberikan mencakup kemampuan dasar yang sangat berguna untuk menunjang kemampuan berkomunikasi baik lisan maupun tertulis. Materi tersebut adalah struktur bahasa Inggris, membaca, dan menyimak. Materi-materi 
struktur bahasa Inggris yang diberikan antara lain Tenses, Verb Pattern, Nouns dan Noun Phrase, Adjective dan Adverb, Passive, Conjuction dan Preposition. Membaca diberikan dengan tujuan agar peserta dapat memiliki kemampuan untuk memahami teks-teks bahasa Inggris yang beragam, baik dari segi tema maupun tingkat kesulitan teks. Materi-materi yang terkait dengan membaca antara lain Vocabulary, Main Ideas, Reference, dan Message. Dengan cakupan materi seperti itu peserta diharapkan dapat memiliki kemampuan memahami teks dari segi isi maupun kosa kata yang digunakan. Kemampuan menyimak merupakan hal yang sangat penting dalam pembelajaran bahasa Inggris sehingga peserta diharapkan dapat memiliki kemampuan memahami teks-teks yang bersifat audio (suara) yang merupakan bagian komunikasi sehari-hari yang sangat dominan. Ketiga kemampuan dasar tersebut merupakan elemen dasar dalam pembelajaran bahasa Inggris, baik untuk tujuan akademik maupun untuk tujuan praktis.

Berdasarkan uraian di atas, tim pelaksana mencoba untuk memberikan sosialisasi Bahasa Inggris Berekuivalensi TOEFL Bagi guru Yayasan Nara Kreatif Jakarta Timur. Dengan adanya sosialisasi ini diharapkan para guru dapat membantu para guru baik guru bahasa Inggris maupun guru non bahasa Inggris untuk memotivasi diri dan mengoptimalkan potensi yang mereka miliki dalam bahasa Inggris sehingga mereka dapat memberikan sumbangan yang berarti bagi sekolah, dan terlebih lagi bagi pengembangan karier mereka sendiri.

\section{METODE PELAKSANAAN}

Metode yang dipilih dalam melaksanakan kegiatan PKM ini adalah pelatihan terutama kepada para guru bahasa Inggris dan non bahasa Inggris di Yayasan Nara Kreatif yang berada di Jakarta Timur. Guru-guru yang diutamakan adalah mereka yang mengajar Bahasa Inggris maupun guru kelas pengampu mata pelajaran lain karena mereka merasa perlu adanya upaya dalam meningkatkan kemampuan bahasa Inggris. Mereka akan diberikan pelatihan berupa solusi kunci-kunci mengatasi problematik menghadapi TOEFL serta diberi oleh-oleh materi yang dapat dipelajari di rumah masing-masing. Untuk mencapai tujuan yang telah ditetapkan, maka kegiatan PKM ini dilakukan dengan menggunakan langkah-langkah sebagai berikut: (1) TOEFL dalam standar internasional

terdapat 64 materi yang keluar dalam ujian. Tentu untuk membahas tersebut membutuhkan durasi waktu yang lama. Namun terdapat strategi dalam pengerjaan. Maka langkah pertama yang perlu dipahami adalah mengetahui strategi menghadapi TOEFL. (2) Melakukan Pre-Tes untuk mengetahui hasil nilai peserta. Sehingga diketahui kelemahan peserta dalam mengerjakan. (3) Pembahasan soal-soal secara umum yang sering kali keluar dalam TOEFL meliputi Listening, Structure, dan Reading. (4) Melakukan Post-Tes untuk mengetahui hasil setelah dilakukan pembahasan materi TOEFL.

Pemberian pelatihan dilakukan oleh tim PKM. Sementara itu Yayasan Nara Kreatif bertugas menyediakan sarana prasarana demi lancarnya kegiatan sosialisasi seperti sumber listrik, tempat, meja dan kursi, unit komputer, dan proyektor. Sosialisasi 
dilaksanakan dengan pendekatan andragogi. Metode pembelajaran lebih banyak demonstrasi, tanya jawab dan praktik. Materi sosialisasi disajikan dengan lebih banyak praktik daripada teori, dengan rasio perbandingan $30 \%$ teori dan $70 \%$ praktik.

\section{HASIL PELAKSANAAN DAN PEMBAHASAN}

Kegiatan PKM ini dilaksanakan secara tatap muka yang diisi dengan ceramah maupun pemaparan umum tentang TOEFL dilanjutkan latihan mengerjakan soal-soal TOEFL. Peserta sosialisasi adalah guru-guru di Yayasan Nara Kreatif Jakarta Timur. Secara keseluruhan peserta sosialisasi berjumlah 15 orang. Pelaksanaan sosialisasi dilakukan selama 3 hari yaitu dimulai pada tanggal 23-25 November 2017.

Selama proses sosialisasi berlangsung, para peserta tampak antusias menyimak materi yang disampaikan oleh para narasumber yang dengan penuh kesabaran memberikan materi kepada peserta dengan diselingi humor. Tanya jawab dan diskusi terjadi manakala ada bagian yang dirasa tidak jelas dan kurang dipahami oleh para peserta. Para peserta diberi kebebasan untuk menyela dan meminta penjelasan kepada narasumber tentang materi yang sulit dipahami. Hal tersebut bertujuan untuk proses sosialisasi lebih efektif, interaktif, dan efisien.

Hasil pre-test yang dilakukan sebelum pelatihan menunjukkan bahwa skor maksimal untuk TOEFL para peserta adalah 343 dan skor minimal 310. Sedangkan, hasil post-test menunjukkan bahwa skor maksimal untuk TOEFL para peserta adalah 477, dan skor minimal 397. Keterbatasan waktu pertemuan mengakibatkan tidak semua materi dapat disampaikan dengan detail. Kegiatan yang diawali dengan ceramah dan demonstrasi ini kemudian dilanjutkan latihan. Dari kegiatan sosialisasi ini terlihat bahwa para peserta yang menjadi khalayak sasaran memang belum pernah dikenalkan dengan TOEFL dan bahkan sebagian besar belum pernah mendengar jenis tes ini, namun peserta sangat antusias untuk mempelajari TOEFL oleh karena sudah adanya pengetahuan dan kesadaran pentingnya TOEFL ini. Dalam sesi Tanya jawab para peserta banyak mengajukan pertanyaan yang secara garis besar dirangkum sebagai berikut: (1) Apa itu TOEFL?, (2) Bagaimana cara mempelajari TOEFL?, (3) Bagaimana menghitung nilai TOEFL?, (4) Berapa waktu yang diperlukan untuk mengerjakan TOEFL?, (5) Di mana saya bisa mempelajari TOEFL?, (6) Di mana saya bisa mengikuti TOEFL?, (7) Berapa biaya untuk mengikuti TOEFL?, (8) Apa kegunaan mengikuti TOEFL?, (9) Apa saja kiat-kiat untuk mengerjakan TOEFL dengan mudah dan cepat?, (10) Apa saja kiat-kiat untuk mendapatkan nilai TOEFL yang bagus?

Hambatan yang terjadi di lapangan selama kami melakukan sosialisasi Bahasa Inggris berekuivalen TOEFL (Test English as a Foreign Language) adalah: (1) Kurangnya sosialisasi dari pihak yayasan kepada seluruh guru dan staf sehingga pada pertemuan pertama sosialisasi hanya beberapa guru dan staf yang hadir. (2) Ada beberapa peserta harus meninggalkan kelas pada saat sosialisasi berlangsung karena ada pekerjaan yang tidak bisa 
ditinggalkan. (3) Waktu yang diberikan sangat terbatas sehingga kami tidak dapat memberikan sosialisasi secara maksimal. Beberapa solusi yang kami lakukan adalah: (1) Kami tetap memberikan modul kepada peserta yang tidak hadir di pertemuan pertama dengan cara menitipkannya kepada rekan guru atau staf terdekat sehingga mereka bisa mengikuti pelatihan di pertemuan berikutnya. (2) Kami mengizinkan peserta yang awalnya meninggalkan ruangan untuk mengikuti kembali sosialisasi dan salah satu tim kami mengulang kembali apa yang sudah dijelaskan dengan harapan mereka mengerti dengan materi yang diberikan. (3) Kami memberikan penghargaan (reward) berupa kenangkenangan bagi seluruh peserta yang telah berpartisipasi aktif dalam sosialisasi Bahasa Inggris berekuivalen TOEFL (Test of English as a Foreign Language).

Hasil yang dicapai dalam kegiatan ini adalah mengenalkan TOEFL kepada para guru di yayasan Nara Kreatif serta mengukur kemampuan TOEFL para guru di yayasan Nara Kreatif, kegiatan pelatihan TOEFL menjadi solusi bagi yayasan Nara Kreatif untuk meningkatkan kemampuan Bahasa Inggris para guru dalam menghadapi persaingan global ini, terutama untuk menghasilkan lulusan yang mampu bersaing, baik untuk melanjutkan ke jenjang pendidikan yang lebih tinggi maupun dalam dunia kerja. Selain itu adapula hasil dari analisa pre-tes dan post-tes menunjukkan adanya peningkatan rata-rata hasil belajar peserta. Hal ini menunjukkan bahwa terdapat peningkatan hasil belajar yang juga dapat diartikan sebagai peningkatan pemahaman materi dan penguasaan strategi dalam mengerjakan soal TOEFL. Hasil wawancara pada pertemuan awal menunjukkan bahwa sebagian dari peserta tidak pernah mempelajari dan mengikuti TOEFL. Mereka sangat antusias untuk mengikuti pelatihan dan berharap mendapatkan pengalaman lebih dan meningkatkan kemampuan Bahasa Inggris mereka. Setelah pelaksanaan pelatihan, tim melakukan evaluasi dan wawancara dengan para peserta, hasil menunjukkan bahwa para peserta mendapatkan pengalaman dan mereka dapat mengetahui mendalam tentang TOEFL dan strategi dalam mengerjakannya. Antusiasme peserta dalam mengikuti pelatihan ini sangat tinggi. Hal ini dibuktikan dengan tingginya rata-rata tingkat kehadiran peserta pada tiap pertemuan. Adapun sesi-sesi dokumentasi kegiatan pelatihan ini adalah sebagai berikut:

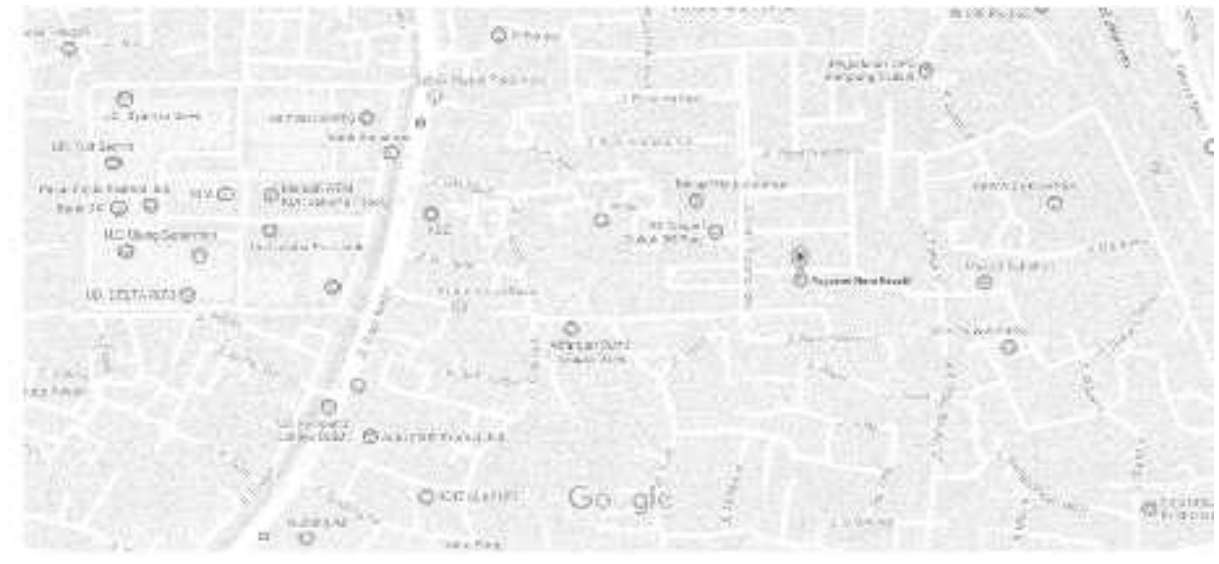

Gambar 1

Peta Wilayah Lokasi Sosialisasi Guru Yayasan Nara Kreatif Jakarta Timur 

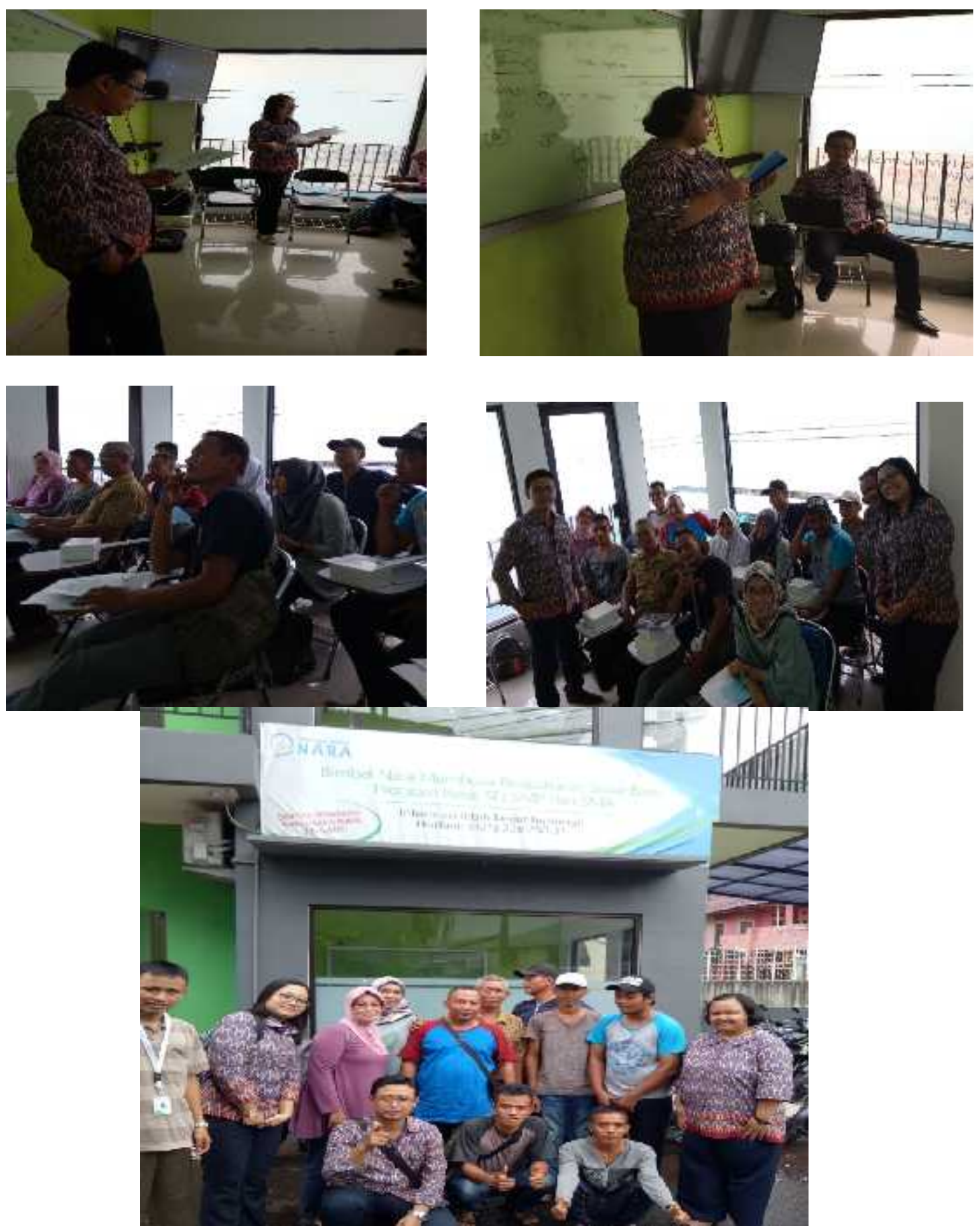

\section{SARAN}

Kegiatan PKM berupa "Sosialisasi Bahasa Inggris Berekuivalen TOEFL (Test of English as a Foreign Language) Bagi Guru Yayasan Nara Kreatif Jakarta Timur" dapat diselenggarakan dengan baik sesuai dengan rencana kegiatan yang telah disusun, dan juga tujuan kegiatan ini yaitu mengenalkan dan mengukur kemampuan TOEFL kepada para 
guru di yayasan Nara Kreatif. Kegiatan ini mendapat sambutan yang sangat baik di mana para peserta terlihat sungguh-sungguh mengikuti pemaparan dan juga mengerjakan contoh-contoh soal dengan mengikuti petunjuk yang telah disampaikan oleh para pemateri. Sosialisasi ini telah mencapai sasaran yaitu dapat memberi pengetahuan dan wawasan kepada para guru di yayasan Nara Kreatif tentang strategi-strategi yang dapat diterapkan dalam menjawab soal-soal TOEFL. Karena keterbatasan waktu tidak semua materi bisa dijelaskan secara detail, namun para peserta mampu dengan baik memahami gambaran umum TOEFL. yang mencakup manfaat, tujuan, jenis, materi, durasi, dan instruksi pengerjaan TOEFL.

Setelah melakukan kegiatan PKM ini, beberapa saran yang layak dipertimbangkan adalah sebagai berikut: (1) Melihat antusias dan jumlah khalayak sasaran, serta materi yang sangat banyak, disarankan agar waktu untuk kegiatan PKM sejenis ini selanjutnya bisa ditambah. (2) Kegiatan PKM sejenis ini juga disarankan agar dalam kegiatan pelatihannya menggunakan media pembelajaran yang lebih interaktif dengan menggunakan aplikasi pembelajaran bahasa Inggris lainnya.

\section{DAFTAR PUSTAKA}

Sharpe, P.J. (2004). How To Prepare For The TOEFL. New Delhi: Galgotia Publication pvt. Ltd.

Phillips, D. (2001). Longman Complete Course for the TOEFL TEST : Preparation for the Computer and Paper Tests. New York: Longman

sCyssco, D.R. (2003). English Grammar Practice for the TOEFL. Jakarta: PUSPA Swara. 
20 J-Abdipamas, Vol 2, No 2, Oktober, 2018 